УДК 354:658.562:61

DOI https://doi.org/10.32836/2310-9653-2020-3.6

С. М. Вовк, доктор наук з державного управління, доцент, професор кафедри організації вищої освіти, управління охороною здоров'я та гігієни Донецького національного медичного університету

Н. С. Половян, кандидат економічних наук, доцент, Донецький національний медичний університет

Т. В. Вовк, викладач кафедри менеджменту невиробничої сфери

Донецького національного університету управління

\title{
ОСОБЛИВОСТІ ТРАНСФОРМАЦЇ̈ МЕХАНІЗМІВ УПРАВЛІННЯ ЯКІСТЮ НАДАННЯ МЕДИЧНИХ ПОСЛУГ
}

Система охорони здоров'я країни перебуває в умовах постійних трансформаційних змін. Як багаторівнева й розгалужена структура, система перетворюється, формує складні підходи щуодо визначення механізмів управління в державному $i$ приватному секторах охорони здоров'я. Саме в них держава відтворює нову систему механізмів управління, розглядати які потрібно в сукупності впливів мезо-, макро- і мікрофакторів із застосуванням нових форм управління на всіх рівнях. Визначено, що проблема підвищення якості надання медичних послуг є стратегічним завданням в рамках модернізації вітчизняної системи охорони здоров'я.

Проаналізовано всі рівні вирішення проблеми впровадження механізмів управління якістю надання медичних послуг, які визначаються певними концепціями розвитку системи охорони здоров'я України, законодавчими та нормативно-правовими актами, які повно або частково вже реалізовані.

Національна стратегія реформування системи охорони здоров'я в Україні визначає ключові проблеми, потенційні напрями і шляхи їх розв'язання для формування нової державної політики у галузі, включаючи нормативні зміни та впровадження нових фінансових механізмів для забезпечення прав людини у сфері охорони здоров'я. За таких умов медична система країни має базуватися на трьох засадничих принципах: орієнтованість на людину, орієнтованість на результат, орієнтованість на втілення кращих технологій та кращого досвіду надання медичних послуг.

Начіональна сфера охорони здоров'я України йде складним шляхом реформувань. Розглядаючи сучасну сферу охорони здоров'я України, можна констатувати: криза та реформи - иі слова за останні роки щільно вплелися в медицину та охорону здоров'я України, на яку обрушилося багато незвичних стереотипів і уявлень. Найбільш суперечливими є механізми держсавного управління галуззю, тому не зменшується науковий дискурс із сучасного розвитку медичної системи.

Суперечливість виникає в теоретичних та практичних поглядах на сферу охорони здоров'я. 3 одного боку, теоретичні дослідження розкривають дію механізмів державного управління, з іншого - практичне впровадження циих дій потребує системного підходу на кожному рівні суб'єктно-об'єктної взаємодії.

3'ясовано, щчо вживані заходи щңодо вдосконалення матеріально-технічної бази медичних організацій і підвищення оплати прачі медичних фахівців не дали очікуваного темпу зростання якості надання медичної допомоги.

Ключові слова: якість, медична послуга, держава, механізми державного управління, трансформаційній перетворення, охорона здоров'я. services

S. M. Vovk, N. S. Polovyan, T. V. Vovk. Features of transformation of mechanisms for quality management of medical

The medical sector of Ukraine is a sphere of public administration, where the main thing is human health. It is the health of the nation that is the main indicator of the development of life in the country and the effectiveness of the public administration system as a whole. From this point of view, the quality of medical care, as a certain system of relations between the state, communities, hospitals, medical professionals and patients, is a key indicator of the state of the health system, the analysis of which makes it possible to separate certain problematic approaches in the formation of mechanisms of state management of the industry.

Improving the quality of medical care is a strategic goal within the framework of modernizing the national healthcare system. The state level of solving this problem is determined by certain concepts of development of the health care system in Ukraine, legislative and regulatory acts that have already been fully or partially implemented. At the same time, the measures taken to improve the material and technical base of medical organizations and increase the remuneration of medical specialists (generally demonstrating a positive effect) did not give the expected rate of growth in the quality of medical care provided.

Until now, the results of sociological surveys of the country demonstrate the population's dissatisfaction with the quality of medical care, especially in regions where there are still disparities in the staffing of narrow specialists in the city and acute personnel hunger in rural areas. There is an effect of "paradoxical medicine", that is, discrepancies between declared and actual indicators.

(C) С. М. Вовк, Н. С. Половян, Т. В. Вовк, 2020 
Taking into account that one of the factors of patients'dissatisfaction with medical services is the lack of availability and quality of medical care, there is a need for a comprehensive assessment of the mechanisms of state management of the quality system of medical services in Ukraine, the professional activities of medical professionals who directly provide medical services to the population, the features of relationships in the "doctor-district-patient" relationship.

The purpose of our research is to study the conditions for implementing management mechanisms of the quality system of medical services, the peculiarities of their transformation in modern socio-economic conditions, and the development of scientifically based proposals. protection.

Key words: quality, medical service, state, mechanisms of public administration, transformational transformation, health

Постановка проблеми. Сьогодні у країні відбувається непростий процес реформування і модернізації суспільних відносин, в тому числі охорони здоров'я. Тому глобальні стратегічні інтереси нашої держави полягають у збереженні і зміцненні здоров'я населення. Саме здоров'я у всіх його проявах є головною рушійною силою суспільного прогресу.

Реформування та модернізація вітчизняної охорони здоров'я спрямовані на організацію та оптимальне функціонування галузі. Однак концептуальні положення реформи досі недостатньо підкріплені методологічним апаратом і науково обгрунтованими принципами, а реальні заходи, спрямовані на досягнення кінцевих результатів, за своєю суттю є недостатніми.

Слід зазначити, що необміркованість і відсутність системного підходу до модернізації та організації системи якості в медичній галузі негативно відбилося на ефективності їі функціонування. Позасистемний підхід до реформування охорони здоров'я з усією очевидністю проявляється на сучасному етапі. Сучасна медична система досі не володіє адекватним набором специфічних соціальних норм і нормативів, вона не орієнтована на політичну, економічну, ідеологічну і ціннісну специфіку сучасного суспільства і тому не може бути повністю інтегрована в його структуру.

Аналіз останніх досліджень і публікацій. Визначення мети функціонування охорони здоров'я дозволяє впливати на якість прийнятих управлінських рішень, у тому числі при наданні медичних послуг. При цьому відбувається постійна трансформація суспільно значущих цілей у власні, внутрішні цілі системи, що призводить до «обюрокрачування» системи, яка починає працювати на себе і в ім’я себе.

Проблеми функціонування системи охорони здоров'я в межах ефективного державного управління сферою якості медичних послуг сьогодні вивчаються багатьма дослідниками. Серед них можна назвати Н. Авраменко, Н. Алексєєва, Ю. Бєляєва, М. Білинську, Л. Бондареву, Н. Борисова, С. Вовк, П. Герасимова, І. Ковальова, Н. Кризину, Д. Карамишева, В. Лехан, Я. Радиша та ін.

Реформи у сфері охорони здоров'я націлені на перетворення, зміну інститутів, медичних установ, вдосконалення механізмів державного управління між ними. За науковими маркуваннями Н. Авраменко [3, с. 97], С. Вовк [4, c. 47] можна виділити чотири типи реформ, де є певні механізми управління якістю медичних послуг.

До перших автори відносять ті, що мають корективний характер, тобто вони не мають за мету змінити основи державного управління, а тільки позбутися деяких рудиментів, застарілих механізмів і введення більш ефективних засобів поліпшення управління охороною здоров'я. Інші носять модернізаційний етап реформування, де метою є подолання відставання від розвинених країн шляхом впровадження нових зразків у підготовці управлінських кадрів, запровадження передових напрямів медичної справи, її організації, у тому числі й механізмів якості. Наступні - це структурне перетворення та спрямування на поліпшення медичного права, впровадження ринкових відносин, розвиток самоуправління, особливо в первинних ланках медичного обслуговування населення. Останні - це системні реформи, націлені на кардинальну зміну основ державного управління охороною здоров’я, враховуючи прогресивні соціально-економічні перетворення у суспільстві, вдосконалення структурно-організаційних та функціональних механізмів управлінської діяльності. Тобто йдеться про системні зрушення в моделі функціонування державного управління, змісті і формі діяльності, правового, фінансового, матеріально-технічного, кадрового механізмів забезпечення контролю та підвищення ефективності медичного обслуговування населення. Українська система охорони здоров’я проходить всі види вищезазначених реформ.

Ключова роль системи охорони здоров'я в сучасній суспільній системі держави зумовлена їі специфікою. Охорона здоров'я, на відміну від інших сфер, має яскраво виражений зовнішній ефект. Завдяки цьому послуги охорони здоров’я прийнято розглядати як соціально-значущі блага. Як будь-яка соціальна система, вона розвивається за своєю специфічною логікою та метою.

Мета статті - дослідження та узагальнення наукових уявлень щодо підвищення якості надання медичних послуг в умовах реформування системи охорони здоров'я України.

Виклад основного матеріалу. Недооцінка зазначених внутрішніх змін у системі породжує парадоксальне явище в сучасній охороні здоров'я - непорівнянність, а іноді і протилежність декларованих зверху змін результатам реформи, що відбувається на практиці. Імовірно, це пов'язано з недостатнім комутуванням цілей проведених 
дій із внутрішніми характеристиками системи. Однак у деяких адміністративних колах продовжує зберігатися думка, що будь-яка зміна в системі охорони здоров’я призведе до поліпшення здоров'я населення.

Слід визначити, що трансформація механізмів державного управління та механізмів державної політики у сфері охорони здоров'я була зумовлена низкою змін у політично-соціальних, правових, кадрових, організаційних аспектах розвитку управління суспільством і державою.

Класичний підхід до управління якістю медичної допомоги та медичними послугами пропонує розглядати ії за такими характеристиками:

1) доступність - оцінюється ступенем, в якому медична допомога може безперешкодно надаватися, незалежно від географічних, економічних, соціальних, культурних, організаційних або мовних чинників [4-6];

2) результативність - це міра, якою лікування пацієнта сприяє поліпшенню його стану або бажаному результату $[5$, с. $14 ; 6$, с. 44$]$;

3) професійна компетентність - визначається рівнем навиків і вмінь, що реалізуються у процесі діяльності людей, які надають медичні послуги, в діяльності керівництва й обслуговуючого персоналу [5, с. 14];

4) безпечність - визначається мірою, в якій система медичної допомоги знижує ризик пошкоджень, інфікування, побічних явищ чи інших збитків у процесі надання медичної допомоги [6, с. 44];

5) особисті взаємини - стосуються якості взаємодії між провайдерами послуг і споживачами, керівництвом і провайдерами медичної допомоги, медичними працівниками і місцевими жителями [4, с. 15; 5, с. 45];

6) економічна ефективність - співвідношення між потребою в обслуговуванні та наявними ресурсами для надання допомоги. Ефективність досягається шляхом надання оптимального обсягу медичної допомоги населенню, тобто більше допомоги найкращої якості, що можливо досягнути за наявних ресурсів [3-5];

7) зручність є тією характеристикою медичного обслуговування, яка безпосередньо не відноситься до клінічної ефективності, але може позитивно вплинути на ступінь задоволеності пацієнта якістю обслуговування. Комфортність визначається зовнішнім виглядом і чистотою приміщень, що використовуються, обладнанням і персоналом, а також заходами щодо забезпечення комфорту і зручності [6, с. 45];

8) безперервність і послідовність - віддзеркалює ступінь, в якому пацієнт одержує необхідне йому медичне обслуговування без перерв, зупинок або зайвих повторень обстежень або лікування [4-6].

Перехід від адміністративно-командної системи до ринкових відносин, розширення самоврядування викликали і загострили протиріччя в політичному і соціально-економічному розвитку, серйозно вплинули на стан державного управління охороною здоров'я.

Система оцінки якості медичних послуг у складі охорони здоров'я має складну ієрархію органів, внаслідок чого необхідне управління цією системою. Однак перш ніж розглядати, як взаємодіє система механізмів державного управління якістю медичних послуг, треба визначити дефініції, які відображають ії сутність.

По-перше, під якістю медичної допомоги треба розуміти процес певної взаємодії між лікарем та пацієнтом, де кваліфікаційна здатність лікаря знижує ризик прогресування захворювання та виникнення нового патологічного процесу, оптимально використовувати наявні ресурси медичної системи та забезпечення пацієнта наданою йому медичною допомогою [6, с. 87].

По-друге, якість медичної допомоги - це комплекс певних характеристик, які можуть підтвердити поліпшення стану здоров'я пацієнта та відповідають певному рівню наданих медичних послуг і допомоги наявним потребам та сучасному рівню доказової медичної науки [7, с. 42].

Якість медичного обслуговування - це надання медичних послуг, за яких ресурси організуються таким чином, щоб із максимальною ефективністю і безпечністю задовольняти медико-санітарні потреби тих, хто найбільш усього потребує допомоги, проводити профілактику і лікування без непотрібних витрат і відповідно до вимог найвищого рівня [7].

Стає зрозуміло, що різноманітні підходи до визначення якості медичних послуг та допомоги потребують врахування класичного підходу до визначення якості, згідно з яким слід розуміти наявність суттєвих ознак, властивостей, особливостей, що відрізняють один предмет або явище від інших [4-7].

Отже, якість медичних послуг можна розглядати як сукупність механізмів державного управління на різних рівнях, окремих властивостей, умов та факторів.

Ми вважаємо, що якість медичних послуг - це відповідність отриманого реального результату у людини і контролю цього результату від надання цих послуг типовому стандарту, що заснований на статистично вірному прогнозі, очікуваному в даних випадках та певній системі, в якій задіяні механізми державного управління для його отримання.

За своєю суттю усі види медичної діяльності, які спрямовані на створення певної системи медичної якості, складаються із трьох компонентів: створення, поліпшення та контроль якості, куди входять усі види діяльності та нагляд за якістю (розробка стандартів, дії менеджменту, аудит, самооцінка, система моніторингу, оцінювання якості, зворотний зв'язок, процес змін) [8]. 
Створення системи управління якістю медичних послуг підпорядковується методології управління та таким принципам [5-10]:

1. Створення медичної допомоги, яка б задовольняла потреби і очікування зовнішнього споживача (пацієнта) і внутрішнього споживача (медичного працівника); проведення соціологічних досліджень серед населення (споживачів) щодо очікування від медичних послуг. Це дозволяє постійно бути поінформованим: хто споживач, які його потреби, бажання і очікування.

2. Системний підхід. Роботу медичної системи можна уявити як сукупність підсистем і процесів, що в них відбуваються. Тому для отримання кращих результатів медичної допомоги необхідно проаналізувати систему, визначити пріоритетні проблеми і прийняти можливі рішення щодо іії зміни. Результати діяльності будь-якої системи визначаються ії побудовою і функціонуванням. Згідно із цим положенням, якщо ми продовжуємо працювати так, як працюємо, то можемо розраховувати лише на ті результати, що зараз маємо. Для досягнення кращих результатів слід змінити систему [5-10].

Виходячи із цього, можна зробити такі висновки:

1) будь-яке поліпшення якості медичних послуг вимагає змін у функціонуванні системи та/або змін побудови. Проте не завжди зміни поліпшують стан медичних послуг і не всі поліпшення зумовлені змінами;

2) якщо ми запроваджуємо зміни в управлінні якістю медичних послуг, то треба змінювати не частини або елементи, а їх взаємодію, бо вдосконалення тільки частини не є результативним;

3) соціологічний аналіз з послідуючою вказівкою на вдосконалення якості послуг не достатній. Ми переконані, що треба змінювати систему, а не діяти засобами мотивації (винагороди), покарання, постійного інспектування тощо, які не можуть змінити ситуацію в бік якості.

3. Командна робота - дає змогу об’єднати зусилля представників різних сторін (управлінців, менеджерів сфери охорони здоров'я, медичних працівників, пацієнтів тощо) під час надання медичних послуг [9-11]. Саме така робота дає змогу використати детальні знання кожного про відповідний елемент галузі, що є принципово важливим для знаходження оптимального рішення зміни системи якості медичних послуг.

4. Наукові методи - допомагають на основі достовірних даних обрати нагальну проблему, оцінити ії розміри і значущість, розробити план дій, що включає зміни процесів і самої системи, поставити експеримент для перевірки правильності намічених змін, оцінити результати експерименту, впровадити в діяльність СО3 зміни, в результаті яких підвищилася якість [8, с. 103].

Причому часом це не менш важко, ніж управління з боку державних органів щодо лікувальних установ. Тим самим залежно від спрямованості і місця впливу можна виділити внутрішні й зовнішні функції управління системою якості медичних послуг.

Внутрішні функції управління знаходяться всередині державного управління системи якості медичних послуг. Їхнє існування зумовлене розгалуженою і різнокомпонентною побудовою системи охорони здоров'я як суб'єкта управління, актуальністю впорядкування й активізації дій його рівней. Цільова орієнтація таких функцій управління полягає в тому, щоб надавати динамічність і законність управління кожному державному органові, вдосконалювати і розвивати його, переводити в стан, що відповідає суспільним потребам у державних механізмах управління.

Сьогодні аналіз результатів роботи механізмів державного управління базується на усталених наукових підходах та затверджених нормативно-правових документах, що, за нашу думку, є недостатнім для оцінки якості медичних послуг і визначення напрямків для їх вдосконалення. Ми вважаємо, цілеспрямований вплив на якість та в цілому на ефективність медичних послуг полягає в розробці індикаторів, які б дозволили забезпечити об’єктивне оцінювання механізмів, їх моніторинг та більш конкретне визначення проблем у якості медичних послуг

Розробка індикаторів за своїм значенням $є$ компонентом стандартизації, в якій встановлюються вимоги, норми, правила, технології, характеристики умов надання медичних послуг. Імплементація європейських підходів до якості медичних послуг полягає в адаптуванні медико-технологічних документів на принципах доказової медицини завдяки впровадженню механізмів державного управління системою якості медичних послуг України, де в нормативно-правовому полі можлива відміна чинності документів, що не відповідають зазначеним принципам. Причому в цьому випадку об’єктами стандартизації становляться всі складові частини медичної допомоги: медичні та фармацевтичні послуги; організаційні технології і технічне забезпечення медичних послуг; інформаційні технології та інше.

Висновки з дослідження і перспективи подальших розвідок у цьому напрямі. Таким чином, ми можемо запропонувати такі напрями щодо розвитку впровадження механізмів державного управління системою якості медичних послуг України: політичний механізм, який формує стратегію, певне бачення та участь урядових організацій щодо поліпшення якості; нормативно-правовий та організаційно-методичний механізми, які здійснюють національну політику в межах органів влади всіх рівнів, формування ресурсів для медичної галузі та соціальний механізм, який пов'язано з покращенням управління в лікувальних закладах

Отже, механізми державного управління, які використовуються в ньому, спрямовані на покращення процесів та результатів медичних послуг через систематичний аналіз складових частин, їх порівняння з визначеними кри- 
теріями, аналіз і впровадження змін на необхідному рівні. Складові частини механізмів управління медичними послугами відбираються та систематично оцінюються. Зміни будуть впроваджуватися на різних рівнях надання послуг - індивідуальному, командному або інституційному.

\section{Список використаних джерел:}

1. Міністерство охорони здоров’я України. URL : https://moz.gov.ua/article/reform-plan/jak-zminilos-stavlennjaukrainciv-do-sistemi-ohoroni-zdorovja-za-tri-roki-analiz-sociologichnih-opituvan-2016-2019-rr (дата звернення: 20.05.2020)

2. Виноградов О.В. Механізми державного управління багатоканальним фінансуванням системи охорони здоров’я України : автореф. дис. на здоб. наук. ступ. канд. наук з держ. упр. : 25.00.02. Київ. 2009. 18 с.

3. Авраменко Н.В. Виникнення механізмів державного регулювання системи охорони здоров'я України. Економіка та держава. № 1. 2011. С. 96-99.

4. Вовк С.М. Системні трансформації охорони здоров'я : монографія ; Донецький державний університет управління, МОН України. Кривий Ріг : вид. Р.А. Козлов. 2017. 315 с.

5. Богомаз В.М. Індикатори якості медичної допомоги та їх роль в управлінні охороною здоров'я. Украӥнський медичний часопис. 2010. № 1 (75) I-II. C. 12-26.

6. Зіменковський А.Б. Системний підхід до оцінки якості медичної допомоги в період реформування охорони здоров’я в Україні. Вісник сой. гігієни та організації охорони здоров’я. 2003. № 2. С. $42-45$.

7. Карамишев Д.В. Управління якістю медичної допомоги в контексті інноваційних перетворень системи охорони здоров’я. Главний врач. 2007. № 1. С. 86-91.

8. Кіщук І. Психологічна травма: пацієнт прагне компенсації. Медична практика: організаційні та правові аспекти. 2012. № 6. С. 42-46.

9. Державна політика у сфері охорони здоров’я : кол. моногр. : у 2 ч. / кол. авт.; упоряд. проф. Я.Ф. Радиш ; передм. та заг.ред. проф. М.М. Білинської, проф. Я.Ф. Радиша. Київ : НАДУ, 2013. Ч. 1. 396 с.

10. Smith M.A., Starkey A.P. TheUtilisationofPrivateSectorGovernanceParadigmsfortheDevelopmentandImplemen tationofInnovationsinthePublicSector. International Journal of Innovation Science. 2010. T. 2. № 3. P. $103-111$.

11. Наказ МО3 України від 22.02.2019 № 446 «Деякі питання безперервного професійного розвитку лікарів». URL : https://moz.gov.ua(дата звернення 20.05.2020).

12. Асоціація міст України. URL : https://www.auc.org.ua/page/munitsipalna-sotsiologiya(дата звернення 20.05.2020).

\section{References:}

1. Ministry of health of Ukraine (1991-2020). [in Ukrainian]

2. Vinogradov, V.V. (2009), Mechanisms of state management of multi-channel financing of the healthcare system of Ukraine: abstract of the dis. na Zdob. nauk. degree of candidate of science with the title of. Kiev [in Ukrainian]

3. Avramenko, N.V. (2011), Emergence of mechanisms of state regulation of the health care system of Ukraine. Economy and state, 1, 96-99 [in Ukrainian].

4. Vovk, S.M. (2017), System transformations of healthcare. Krivoy Rog: publishing house of R. A. Kozlov [in Ukrainian].

5. Bogomaz, V.M. (2010), Indicators of the quality of medical care and their role in health care management. Ukrainian medical journal, 1(75) I-II, 12-26 [in Ukrainian]

6. Zymenkovsky, A.B. (2003), System approach to assessing the quality of medical care in the period of healthcare reform in Ukraine. Bulletin of SOC. hygiene and health organization, 2, 42-45 [in Ukrainian].

7. Karamyshev, D.V. (2007), Quality management of medical care in the context of innovative transformations of the healthcare system. Chief doctor, 1(67), 86-91 [in Ukrainian]

8. Kischuk, I.B. (2012), Psychological trauma: the patient wants compensation. Medical practice: organizational and legal aspects, 6, 42-46 [in Ukrainian].

9. Radysh, Ya.F., Belinskaya, M.M., Radica, J.F. (2013). State policy in the sphere of health care. Prem. and the General editorship, Part 1. 396 [in Ukrainian].

10. Smith, M.A., Starkey, A.P. The Utilisationof Private Sector Governance Paradigmsforthe Developm entandIm plementationo fInnovations inthe Public Sector. International Journal of Innovation Science, 3. (2), 103-111 [in Ukrainian].

11. Order of the Ministry of health of Ukraine from № 446 (2019, February 22). Some issues of continuous professional development of doctors [in Ukrainian].

12. Association of cities of Ukraine. (2020) [in Ukrainian]. 